\title{
The Aryl-hydrocarbon Receptor (AhR) as a Therapeutic Target in Human Breast Cancer
}

\author{
Julie M Hall \\ Campbell University, College of Pharmacy \& Health Sciences, Buies Creek, USA \\ *Corresponding author: Julie M Hall, Campbell University, College of Pharmacy \& Health Sciences, Buies Creek, USA, Tel: 910-893-1698; E-mail: \\ halljm@campbell.edu
}

Received date: May 29, 2014, Accepted date: July 16, 2014, Published date: July 23, 2014

Copyright: @ 2014 Hall JM. This is an open-access article distributed under the terms of the Creative Commons Attribution License, which permits unrestricted use, distribution, and reproduction in any medium, provided the original author and source are credited.

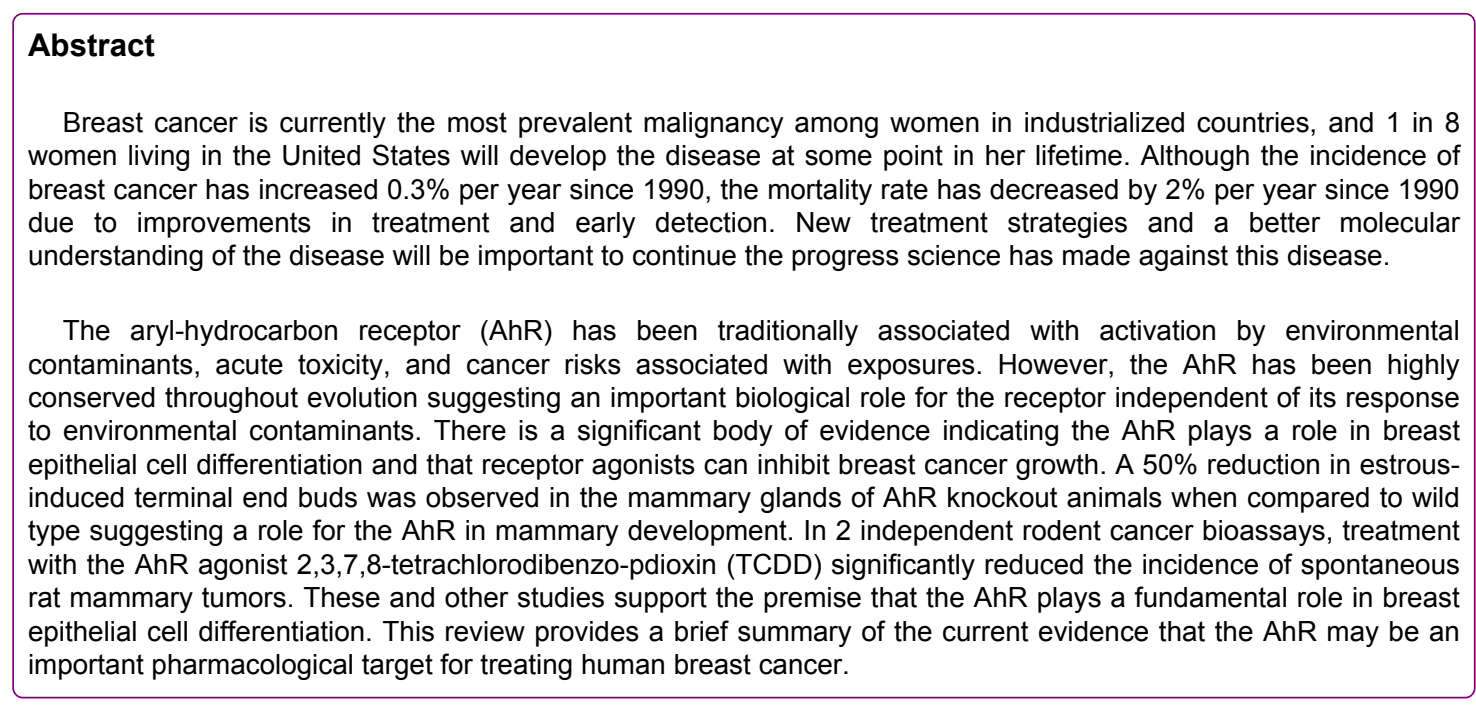

Keywords: Aryl-hydrocarbon receptor; Breast cancer; AhR; Estrogen receptor; TCDD; Metastasis; Therapeutic target

\section{Introduction}

Breast cancer is currently the most prevalent malignancy among women in industrialized countries, and 1 in 8 women living in the United States will develop the disease at some point in her lifetime [1]. Although the incidence of breast cancer has increased $0.3 \%$ per year since 1990 , the mortality rate has decreased by $2 \%$ per year since 1990 due to improvements in treatment and early detection [1]. New treatment strategies and a better molecular understanding of the disease will be important to continue the progress science has made against this disease.

The aryl-hydrocarbon receptor (AhR) has been traditionally associated with activation by environmental contaminants, acute toxicity, and cancer risks associated with exposures. However, the AhR has been highly conserved throughout evolution [2] suggesting an important biological role for the receptor independent of its response to environmental contaminants. There is a significant body of evidence indicating the AhR plays a role in breast epithelial cell differentiation and that receptor agonists can inhibit breast cancer growth. A 50\% reduction in estrous-induced terminal end buds was observed in the mammary glands of AhR knockout animals when compared to wild type suggesting a role for the AhR in mammary development [3]. In 2 independent rodent cancer bioassays, treatment with the AhR agonist 2,3,7,8-tetrachlorodibenzo-p-dioxin (TCDD) significantly reduced the incidence of spontaneous rat mammary tumors $[4,5]$. These and other studies support the premise that the AhR plays a fundamental role in breast epithelial cell differentiation. This review provides a brief summary of the current evidence that the AhR may be an important pharmacological target for treating human breast cancer.

\section{The Aryl-Hydrocarbon Receptor (AhR) Mechanism of Action}

The identification of the AhR originated in early toxicology studies that observed an increase in mono-oxygenase activity following exposure to polyaromatic hydrocarbons. Additional studies using a highly potent inducer, 2,3,7,8-tetrachlorodibenzo-p-dioxin (TCDD), showed that binding to a cytosolic receptor was proportional to the induction of mono-oxygenase activity [6]. The gene encoding the AhR was subsequently cloned and characterized across multiple species [7-9]. Further molecular characterization of the AhR demonstrated that the receptor is highly conserved $[2,10]$ and plays a significant role in tissue development [1,11-13]. For example, targeted disruption of the AhR in the mouse results in compromised immune function [14], and deficiencies in the development of several tissues including ovarian follicles [15], seminal vesicles [16], fetal vasculature [17], and mammary glands [18].

The AhR is a ligand-activated transcription factor and a member of the basic-helix-loop-helix Per-Arnt-Sim (bHLH-PAS) family of proteins [19]. In an unliganded state, the AhR exists in the cytoplasm 
bound to chaperones HSP90, p23, and other proteins (Figure 1). Ligand binding induces translocation of the AhR into the nucleus, where it dissociates from cellular chaperones and heterodimerizes with ARNT (aryl-hydrocarbon receptor nuclear translocator). AhR/ARNT heterodimers bind to genomic dioxin response elements (DREs), which initiates transcription of genes within the AhR gene battery, including Cyp1a1, Cyp1b1, Aldh3, Nqo1, and Gsta1 [20-23]. Interactions with other cellular proteins have been identified leading to a proposed role for the AhR in many signaling pathways including the retinoblastoma $(\mathrm{Rb})$ protein and cell cycle [24,25], estrogen receptor (ER) signaling [26] and RELA and NFKB signaling [27].

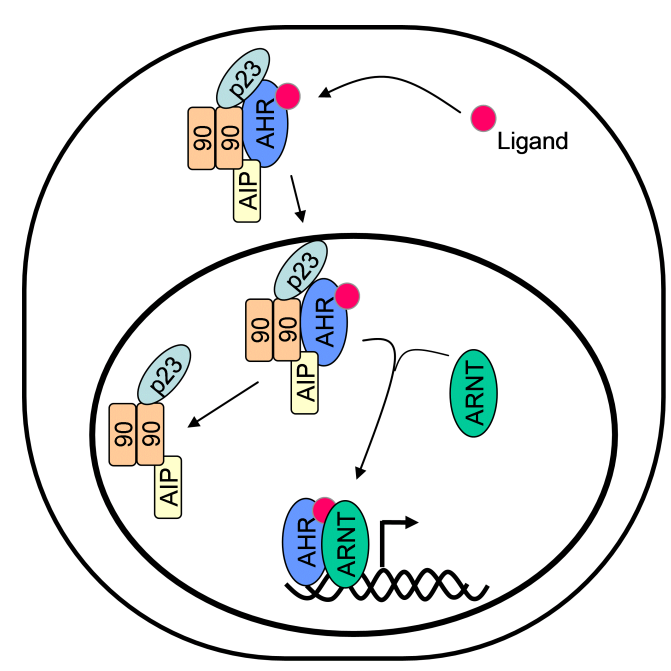

Figure 1: Schematic representation of the AhR signaling pathway

\section{Role of the AhR in Tissue Development}

The AhR gene is highly conserved across both vertebrate and invertebrate species $[2,10]$. The existence of ancestral AhR orthologs that either bind no ligand or bind a range of ligands that are unique from those recognized by the vertebrate receptors suggest that its role in regulating xenobiotic metabolism is a recent adaptation [2,28]. Apart from the evolutionary conservation, evidence for a role of the $\mathrm{AhR}$ in tissue development can be seen from the characterization and disruption of the AhR in model organisms. In Drosophila melanogaster, mutation of the AhR ortholog Spineless lead to alterations in appendage development [29], neuron morphology [30], and photoreceptor development [31].

In Caenorhabditis elegans, disruption of the AhR ortholog AHR-1 leads to alterations in neuronal development [32]. In a more relevant mammalian model, expression of the AhR occurs early in development in preimplantation embryos [33] and at gestational days 10 to 12 with high expression in many neuronal tissues [34]. Expression of the AhR expands to a large number of tissues by gestational day 13.5 to 15.5 indicating a potentially broad functional role in tissue development [34]. Targeted disruption of the AhR in mice has revealed obligatory roles for the receptor in multiple tissues including liver, the immune and cardiovascular systems, and the male and female reproductive systems [14-18]. Notably, a 50\% reduction in estrous-induced terminal end buds was observed in the mammary glands of AhR null animals when compared to wild types suggesting a role for the AhR in mammary development [3].

\section{Ligands of the AhR}

Following the early studies characterizing the increase in monooxygenase activity due to polyaromatic hydrocarbon exposure, a significant research effort has ensued to identify and characterize both endogenous and xenobiotic ligands for the AhR. Although the endogenous ligand for the $\mathrm{AhR}$ is the subject of continued debate, multiple candidates have been proposed including indigoids, equilenin, arachidonic acid metabolites, heme metabolites, tryptophan metabolites, and UV photoproducts of tryptophan [35]. In addition, dietary compounds and nonligand activators of the AhR have been identified [35]. For the xenobiotic ligands, the most well-known are the halogenated dioxins, polychlorinated biphenyls (PCBs), and polyaromatic hydrocarbons (PAHs) [20].

The halogenated dioxins include the dibenzo-p-dioxins and dibenzofurans that are formed during both combustion and industrial processes such as waste incineration, forest fires, pesticide manufacturing, and paper pulp bleaching [36]. Within this class, 2,3,7,8-tetrachlorodibenzo-p-dioxin (TCDD) and 2,3,7,8tetrachlorodibenzofuran (TCDBF) are prototypical AhR agonists due to their potency and efficacy in receptor activation [20]. For the PCBs, the coplanar congeners with adjacent halogens in the lateral positions of each ring and no halogen atoms near the biphenyl bridge are the most potent AhR agonists [37]. These chemicals are used in a variety of commercial products including flame retardants, adhesives, transformers and capacitors, lubricants, and fluorescent light ballasts [38]. Finally, the PAHs are a large class of AhR agonists that contain four or more benzene rings [39]. Prototype AhR ligands in this category include benzo[a]pyrene and 3-methylchloranthrene. PAHs are found as byproducts of combustion processes and are typically much less potent than TCDD or the coplanar PCBs.

\section{Adverse Responses to AhR Ligand Activation}

The effects of AhR activation have been primarily characterized using xenobiotic ligands such as TCDD, PCBs, and PAHs. For the classical AhR agonist TCDD, sufficient doses can cause cancer, immune dysfunction, wasting, chloracne, ovarian failure, and birth defects [20,40-42]. Both AhR null animals and mice with a mutation in the DNA binding domain of the AhR are refractive to the toxic effects of TCDD, suggesting that the AhR and its binding to DNA are required to these effects $[43,44]$. For human cancer, epidemiological data from occupationally exposed workers have established a clear association between exposure to TCDD and increased risk for all combined cancers and for lung cancer [45]. The magnitude of the increased risk in these studies is generally low, but it is higher in subcohorts considered to have the highest exposure to TCDD [45]. In the rat, three separate bioassays have been performed $[4,5,46]$.

In the most recent bioassay by the National Toxicology Program, an increased incidence was observed for cholangiocarcinomas and hepatocellular adenomas of the liver, cystic keratinizing epithelioma of the lung, gingival squamous cell carcinoma of the oral mucosa, and squamous cell carcinoma of the uterus [5]. There is substantially less information regarding potential adverse responses for potential endogenous or dietary ligands of the AhR with the majority of exposure occurring for relatively short time periods. Exposure of up to $50 \mathrm{mg} / \mathrm{kg}$ of indigo or indirubin per day for a period of 3 days had little effect on the rat liver [47]. Similarly, exposure mice to $20 \mathrm{mg} / \mathrm{kg}$ of equilenin per day for 3 days had no reported effects [48]. Longer exposures have been performed for indole-3-carbinol (I3C) (a 
component of cruciferous vegetables) and its metabolite diindolylmethane (DIM). In exposures lasting up to one year, there were no observable differences grossly or histologically between groups and no changes in blood chemistry except that male rats treated with high doses of I3C exhibited higher serum levels of 25hydroxy-vitamin D3 [49].

\section{Protective Role of the AhR in Breast Cancer}

While historically AhR agonists have been viewed as tumor promoters, combined epidemiological, animal bioassay, and molecular data indicate that this is an oversimplification. Examination of a population exposed to TCDD following an industrial accident in Seveso, Italy in 1976 showed a positive correlation between TCDD exposure and sarcomas, cancers in the prostate, lung, bladder and digestive tract, those in hematopoietic and lymphatic tissues, and all cancers combined [50], supporting previous studies of occupational workers [45]. However, a significant decrease in breast and endometrial cancer was also evident in exposed individuals [50]. More recently, a report following a population exposed to dioxin emissions from a municipal waste incinerator noted a significant decrease in incidence of invasive breast cancer in women living in the highest exposed zone [51].

The reduction in breast cancer observed in the human studies is supported by two independent rodent experiments showing a significant decrease in spontaneous mammary tumor incidence following a two-year exposure $[4,5]$. In an initiation-promotion model, an absence of mammary tumors was observed in rats administered TCDD compared with a $36 \%$ incidence in control animals [52]. Similarly, exposure to TCDD at sub-toxic doses decreased 7,12dimethylbenz[a]anthracene (DMBA)-induced mammary tumors by $72 \%$ and, in a subset of animals, the original tumors were no longer detectable [53]. In contrast, control animals displayed a $390 \%$ increase in tumor volume over the same time period. Finally, in animals harboring ER+ human breast cancer cell xenographs, TCDD was found to completely suppress hormone-stimulated tumor growth [54]. These results suggest that, similar to many nuclear receptor agonists, the underlying biological responses to AhR activation are context specific.

\section{Cross-Talk between the AhR and Estrogen Receptor a (ERa) Signaling Pathways}

Cross-talk between the AhR and ERa signaling pathways occurs at multiple levels and is dependent on cellular context. In the promoters of many estrogen-inducible genes (e.g., pS2, cathepsin D, c-fos), binding sites for the AhR-ARNT complex (DREs) are adjacent to or overlap those of the ERa providing a means for the direct transcriptional inhibition of ER $\alpha$ [55-57]. The AhR-ARNT complex can also compete with ER $\alpha$ for coactivators, thereby dampening the transcriptional response [58]. On a post-translational level, liganded AhR can antagonize estrogen signaling by facilitating assembly of an ubiquitin ligase complex that promotes proteasomal degradation of $\mathrm{ER} \alpha$ [59]. Finally, the AhR gene battery includes the cytochrome p450s Cypla1 and Cyp1b1 [20-23]. Upregulation of these enzymes results in an increase in estrogen metabolism and depletion of hormone levels $[60,61]$.

The functional consequences of the antagonistic AhR-ER cross-talk are apparent in breast cancer cells. In growth assays, TCDD was shown to completely reverse the proliferative effects of estrogen in human breast cancer cells [54,62]. These observations have been recapitulated in vivo. In a nude mice xenograft model, TCDD suppressed estrogen-dependent tumor growth [54] and in a rat mammary tumor model, co-treatment of an AhR ligand with the antiestrogen tamoxifen was shown to completely inhibit growth of carcinogen-induced mammary tumors [63].

\section{The Effects of AhR on Proliferation and the Cell Cycle}

Apart from antagonistic effects on ERa signaling, the AhR may also display protective effects against human breast cancer by regulation of key processes required for breast cancer cell growth, cell cycle control, and cell migration. A number of studies have investigated the role of the AhR in cancer cell proliferation. Paradoxically, the AhR appears to facilitate growth in the absence of ligand, while the agonist-activated receptor displays marked anti-proliferative effects in cancer cells. For example, transfection of breast cancer cells with AhR siRNA is growthinhibitory [64,65]. Similarly, AhR-deficient hepatoma cells (AhR-D) proliferate at a slower rate than wild-type cells (Hepa 1c1c7), and ectopic expression of the AhR in the AhR-D cells increases their growth to the rate of wild-type cells [66]. In contrast, a ligand-bound AhR inhibits cell growth in a wide array of breast cancer cell lines representing the major breast cancer subtypes, including both those positive and negative for ER, Progesterone Receptor (PR), and Human Epidermal Growth Factor 2 (HER2) [3,62,67-70].

It is now apparent that AhR-mediated suppression of cell growth involves G1 cell cycle arrest [25,71-74]. The cell cycle arrest coincides with association of the AhR with the hypophosphorylated and active form of $\mathrm{Rb}$ to form transcriptional repression complexes on several E2F-regulated genes required for S-phase progression [24,25]. In the absence of ligand, however, the AhR facilitates cell cycle progression by forming a complex with CDK4 and Cyclin D1 [74]. Thus, AhR agonists may function as a molecular switch in cancer cells, converting a basal AhR with growth-promoting activities into a potent antiproliferative factor.

\section{Evidence for a Protective Role of the AhR in Breast Cancer Cell Metastasis}

In addition to cell growth and cell cycle regulation, the AhR has been shown to regulate genes involved in metastasis. Breast tumors most often metastasize to the lung and bone. These organs produce and secrete a chemokine, CXCL12, which attracts breast cancer cells expressing its receptor, CXCR4, on their cell surface [75]. In a recent study, TCDD was shown to down regulate both CXCR4 and CXCL12 in a breast cancer cell line and decrease cell migration towards a CXCL12 gradient [76]. While the consequences of CXCL12 suppression in these cells are unclear, the study demonstrated TCDD may be adequate in preventing breast cancer cells from migrating to areas with high CXCL12 expression [76].

There is emerging evidence that ligand activation of the AhR can inhibit multiple aspects of the metastatic process. In a panel of breast cancer cell lines that represent the 3 major breast cancer subtypes (ER and PR-positive, HER2-positive, and triple-receptor negative), it was found that agonist-activated AhR inhibited cell invasiveness and motility and prevented anchorage-independent growth [65]. Knockdown of the AhR with siRNAs demonstrated that the inhibition of invasiveness was receptor-dependent and endogenous receptor activity was protective in each cell type examined [65]. Likewise, AhR agonists were found to promote differentiation of breast cancer cells 
and mammary cancer stem cells into cells that displayed the phenotypic markers of normal breast epithelial gland cells [65]. Thus, the AhR plays an important role in mammary epithelial differentiation and, as such, represents a promising therapeutic target for a range of phenotypically distinct human breast cancers.

\section{The AhR as a Potential Therapeutic Target for Human Breast Cancers}

Analogous to the selective estrogen receptor modulator (SERM) concept, it has been proposed that selective AhR modulators (SAhRMs) exist that are capable of activating the specific signaling pathways involving the protective effects of the AhR in breast cancer while limiting activation of those pathways leading to the toxic effects [77]. Evidence for the feasibility of this concept is mounting. First, non-traditional AhR ligands have been identified that are capable of activating the receptor without association with the ligand binding pocket [35]. Second, similar to steroid hormone receptors [78], different ligands induce unique conformational changes in the AhR that facilitate interaction with different transcriptional cofactors [79] On a functional level, the AhR agonists I3C, DIM and a series of DIM analogs were shown to effectively inhibit the growth of estrogendependent and independent breast cancer cells and tumors in a manner comparable to TCDD [67-70,72,80]. Structure-activity studies using the DIM analogs showed that specific methyl and dihalosubstitutions could further enhance the anticancer effects above those substantial effects seen for DIM alone $[67,68,80]$. AhR agonists can also be optimized for tissue-selective responses. The AhR agonist 6methyl-1,3,8-trichlorodibenzofuran (6-MCDF) was found to synergize with tamoxifen to inhibit growth of mammary tumors in rodents while inhibiting the undesirable estrogenic effects of tamoxifen in the uterus and did not interfere with the bone-protective actions of tamoxifen in ovarectomized animals [63]. Importantly, effective doses of neither DIM nor 6-MCDF produced the adverse side effects observed with TCDD exposure $[49,67,81,82]$.

\section{The AhR as a Potential Therapeutic Target for ER- negative Human Breast Cancers}

As put forth above, breast cancers are inherently diverse with respect to hormone and growth factor receptor expression and are typically broken down into subtypes based on ER, PR, and HER2 status. The tumor subtype can impact the growth and aggressiveness of the disease as well as predict the response to different chemotherapeutics [83, 84]. Tumors lacking expression of all 3 receptors (triple-negative) are typically the most challenging to treat due to their aggressive natures and the absence of a pliable drug target.

Unlike the available ER-targeted and growth factor-targeted therapeutics for breast cancer, AhR modulators may also have utility in prevention and treatment of triple-negative tumors. In a recent study the SERM Raloxifene, used clinically in prevention of ERpositive breast cancers, was shown to prevent growth and promote regression of triple-negative breast tumors in mice [85]. A second study soon followed that implicated an AhR-dependent mechanism; raloxifene was shown to activate the $\mathrm{AhR}$, and as a consequence, induce apoptosis of triple-negative breast cancer cells with no effects on normal mammary epithelial cells [86].

Other AhR ligands have recently been identified as promising therapeutics for ER-negative breast cancers. The synthetic flavonoid aminoflavone, an AhR agonist, is currently in Phase 2 clinical trials.
Several recent studies that this agent induces DNA damage and displays anti-proliferative, cytotoxic, and apoptotic activities in multiple cancer cell types including triple-negative breast [87-90]. Finally, as mentioned earlier, the AhR agonists I3C, DIM and a series of DIM analogs were shown to effectively inhibit the growth and invasiveness of ER-negative breast cancer cells and tumors $[65,70,72,80]$. Thus, it appears that the AhR hold tremendous potential as a pliable drug target for treatment of estrogen-independent breast cancers.

\section{Summary and Significance}

The current statistics associated with breast cancer reflect both its importance in women's health and the progress we have made towards understanding and treating the disease. The fact that the incidence and mortality of breast cancer has not declined at the same rate as other major causes of death speaks to the unmet need for both new therapeutic targets and approaches. A series of mechanistically distinct therapeutics are currently in clinical use for breast cancer, including those targeting estrogen and growth factor signaling pathways. However, it has become clear that breast cancer is a heterogeneous disease. Each cancer has its own molecular and biochemical makeup and, consequently, there exists no single drug or drug class that will be sufficient to effectively eliminate the disease in all afflicted individuals. This realization has continued to fuel efforts aimed at further molecular characterization of the disease, and these efforts have led to identification of potential and promising new drug targets such as the AhR.

\section{References}

1. ACS (2009) Breast cancer facts and figures.

2. Hahn ME (2002) Aryl hydrocarbon receptors: diversity and evolution. Chem Biol Interact 141: 131-160.

3. Hushka LJ, Williams JS, Greenlee WF (1998) Characterization of 2,3,7,8tetrachlorodibenzofuran-dependent suppression and $\mathrm{AH}$ receptor pathway gene expression in the developing mouse mammary gland. Toxicol Appl Pharmacol 152: 200-210.

4. Kociba RJ, Keyes DG, Beyer JE, Carreon RM, Wade CE, et al. (1978) Results of a two-year chronic toxicity and oncogenicity study of 2,3,7,8tetrachlorodibenzo-p-dioxin in rats. Toxicol Appl Pharmacol 46: 279-303.

5. National Toxicology Program (2006) Toxicology and carcinogenesis studies of a mixture of 2,3,7,8-tetrachlorodibenzo-p-dioxin (TCDD) (Cas No. 1746-01-6), 2,3,4,7,8-pentachlorodibenzofuran (PeCDF) (Cas No. 57117-31-4), and 3,3',4,4',5-pentachlorobiphenyl (PCB 126) (Cas No. 57465-28-8) in female Harlan Sprague-Dawley rats (gavage studies). Natl Toxicol Program Tech Rep Ser 526:1-180.

6. Poland A, Clover E, Kende AS, DeCamp M, Giandomenico CM (1976) $3,4,3^{\prime}, 4^{\prime}$-Tetrachloro azoxybenzene and azobenzene: potent inducers of aryl hydrocarbon hydroxylase. Science 194: 627-630.

7. Burbach KM, Poland A, Bradfield CA (1992) Cloning of the Ah-receptor cDNA reveals a distinctive ligand-activated transcription factor. Proc Natl Acad Sci U S A 89: 8185-8189.

8. Ema M, Sogawa K, Watanabe N, Chujoh Y, Matsushita N, et al. (1992) cDNA cloning and structure of mouse putative Ah receptor. Biochem Biophys Res Commun 184: 246-253.

9. Dolwick KM, Schmidt JV, Carver LA, Swanson HI, Bradfield CA (1993) Cloning and expression of a human Ah receptor cDNA. Mol Pharmacol 44: 911-917.

10. Wang Y, Wang Q, Wu B, Li Y, Lu G (2013) Correlation between TCDD acute toxicity and aryl hydrocarbon receptor structure for different mammals. Ecotoxicol Environ Saf 89: 84-88. 
11. Qin H, Powell-Coffman JA (2004) The Caenorhabditis elegans aryl hydrocarbon receptor, AHR-1, regulates neuronal development. Dev Biol 270: 64-75.

12. Kim MD, Jan LY, Jan YN (2006) The bHLH-PAS protein Spineless is necessary for the diversification of dendrite morphology of Drosophila dendritic arborization neurons. Genes Dev 20: 2806-2819.

13. Wernet MF, Mazzoni EO, Celik A, Duncan DM, Duncan I, et al. (2006) Stochastic spineless expression creates the retinal mosaic for colour vision. Nature 440: 174-180

14. Fernandez-Salguero P, Pineau T, Hilbert DM, McPhail T, Lee SS, et al. (1995) Immune system impairment and hepatic fibrosis in mice lacking the dioxin-binding Ah receptor. Science 268: 722-726.

15. Baba T, Mimura J, Nakamura N, Harada N, Yamamoto M, et al. (2005) Intrinsic function of the aryl hydrocarbon (dioxin) receptor as a key factor in female reproduction. Mol Cell Biol 25: 10040-10051.

16. Baba T, Shima Y, Owaki A, Mimura J, Oshima M, et al. (2008) Disruption of aryl hydrocarbon receptor (AhR) induces regression of the seminal vesicle in aged male mice. Sex Dev 2: 1-11.

17. Lahvis GP, Lindell SL, Thomas RS, McCuskey RS, Murphy C, et al. (2000) Portosystemic shunting and persistent fetal vascular structures in aryl hydrocarbon receptor-deficient mice. Proc Natl Acad Sci U S A 97: 10442-10447.

18. Hushka LJ, Williams JS, Greenlee WF (1998) Characterization of 2,3,7,8tetrachlorodibenzofuran-dependent suppression and $\mathrm{AH}$ receptor pathway gene expression in the developing mouse mammary gland. Toxicol Appl Pharmacol 152: 200-210.

19. Gu YZ, Hogenesch JB, Bradfield CA (2000) The PAS superfamily: sensors of environmental and developmental signals. Annu Rev Pharmacol Toxicol 40: 519-561.

20. Poland A, Knutson JC (1982) 2,3,7,8-tetrachlorodibenzo-p-dioxin and related halogenated aromatic hydrocarbons: examination of the mechanism of toxicity. Annu Rev Pharmacol Toxicol 22: 517-554.

21. Paulson KE, Darnell JE Jr, Rushmore T, Pickett CB (1990) Analysis of the upstream elements of the xenobiotic compound-inducible and positionally regulated glutathione S-transferase Ya gene. Mol Cell Biol 10: 1841-1852.

22. Favreau LV, Pickett CB (1991) Transcriptional regulation of the rat $\mathrm{NAD}(\mathrm{P}) \mathrm{H}$ :quinone reductase gene. Identification of regulatory elements controlling basal level expression and inducible expression by planar aromatic compounds and phenolic antioxidants. J Biol Chem 266 4556-4561.

23. Asman DC, Takimoto K, Pitot HC, Dunn TJ, Lindahl R (1993) Organization and characterization of the rat class 3 aldehyde dehydrogenase gene. J Biol Chem 268: 12530-12536.

24. Elferink CJ (2003) Aryl hydrocarbon receptor-mediated cell cycle control. Prog Cell Cycle Res 5: 261-267.

25. Marlowe JL, Knudsen ES, Schwemberger S, Puga A (2004) The aryl hydrocarbon receptor displaces $\mathrm{p} 300$ from E2F-dependent promoters and represses S phase-specific gene expression. J Biol Chem 279: 29013-29022.

26. Ohtake F, Takeyama K, Matsumoto T, Kitagawa H, Yamamoto Y, et al. (2003) Modulation of oestrogen receptor signalling by association with the activated dioxin receptor. Nature 423: 545-550.

27. Kim DW, Gazourian L, Quadri SA, Romieu-Mourez R, Sherr DH, et al. (2000) The RelA NF-kappaB subunit and the aryl hydrocarbon receptor (AhR) cooperate to transactivate the c-myc promoter in mammary cells. Oncogene 19: 5498-5506.

28. McMillan BJ, Bradfield CA (2007) The aryl hydrocarbon receptor sans xenobiotics: endogenous function in genetic model systems. Mol Pharmacol 72: 487-498.

29. Duncan DM, Burgess EA, Duncan I (1998) Control of distal antennal identity and tarsal development in Drosophila by spineless-aristapedia, a homolog of the mammalian dioxin receptor. Genes Dev 12: 1290-1303.
30. Kim MD, Jan LY, Jan YN (2006) The bHLH-PAS protein Spineless is necessary for the diversification of dendrite morphology of Drosophila dendritic arborization neurons. Genes Dev 20: 2806-2819.

31. Wernet MF, Mazzoni EO, Celik A, Duncan DM, Duncan I, et al. (2006) Stochastic spineless expression creates the retinal mosaic for colour vision. Nature 440: 174-180.

32. Qin H, Powell-Coffman JA (2004) The Caenorhabditis elegans aryl hydrocarbon receptor, AHR-1, regulates neuronal development. Dev Biol 270: 64-75.

33. Peters JM, Wiley LM (1995) Evidence that murine preimplantation embryos express aryl hydrocarbon receptor. Toxicol Appl Pharmacol 134: 214-221.

34. Abbott BD, Birnbaum LS, Perdew GH (1995) Developmental expression of two members of a new class of transcription factors: I. Expression of aryl hydrocarbon receptor in the C57BL/6N mouse embryo. Dev Dyn 204: 133-143.

35. Nguyen LP, Bradfield CA (2008) The search for endogenous activators of the aryl hydrocarbon receptor. Chem Res Toxicol 21: 102-116.

36. Shibamoto T, Yasuhara A, Katami T (2007) Dioxin formation from waste incineration. Rev Environ Contam Toxicol 190: 1-41.

37. Poland A, Glover E (1977) Chlorinated biphenyl induction of aryl hydrocarbon hydroxylase activity: a study of the structure-activity relationship. Mol Pharmacol 13: 924-938.

38. Lucena RA, Allam MF, Jiménez SS, Villarejo ML (2007) A review of environmental exposure to persistent organochlorine residuals during the last fifty years. Curr Drug Saf 2: 163-172.

39. Barron MG, Heintz R, Rice SD (2004) Relative potency of PAHs and heterocycles as aryl hydrocarbon receptor agonists in fish. Mar Environ Res 58: 95-100.

40. Pohjanvirta R, Tuomisto J (1994) Short-term toxicity of 2,3,7,8tetrachlorodibenzo-p-dioxin in laboratory animals: effects, mechanisms, and animal models. Pharmacol Rev 46: 483-549.

41. Schmidt JV, Bradfield CA (1996) Ah receptor signaling pathways. Annu Rev Cell Dev Biol 12: 55-89.

42. Matikainen T, Perez GI, Jurisicova A, Pru JK, Schlezinger JJ, et al. (2001) Aromatic hydrocarbon receptor-driven Bax gene expression is required for premature ovarian failure caused by biohazardous environmental chemicals. Nat Genet 28: 355-360.

43. Peters JM1, Narotsky MG, Elizondo G, Fernandez-Salguero PM Gonzalez FJ, et al. (1999) Amelioration of TCDD-induced teratogenesis in aryl hydrocarbon receptor (AhR)-null mice. Toxicol Sci 47: 86-92.

44. Bunger MK, Glover E, Moran SM, Walisser JA, Lahvis GP, et al. (2008) Abnormal Liver Development and Resistance to 2,3,7,8Tetrachlorodibenzo-p-dioxin Toxicity in Mice Carrying a Mutation in the DNA Binding Domain of the Aryl Hydrocarbon Receptor. Toxicol Sci 106: 83-92.

45. [No authors listed] (1997) IARC Working Group on the Evaluation of Carcinogenic Risks to Humans: Polychlorinated Dibenzo-Para-Dioxins and Polychlorinated Dibenzofurans. Lyon, France, 4-11 February 1997. IARC Monogr Eval Carcinog Risks Hum 69: 1-631.

46. National Toxicology Program (1982) Carcinogenesis Bioassay of 2,3,7,8Tetrachlorodibenzo-p-dioxin (CAS No. 1746-01-6) in Osborne-Mendel Rats and B6C3F1 Mice (Gavage Study). Natl Toxicol Program Tech Rep Ser 209: 1-195.

47. Peter Guengerich F, Martin MV, McCormick WA, Nguyen LP, Glover E, et al. (2004) Aryl hydrocarbon receptor response to indigoids in vitro and in vivo. Arch Biochem Biophys 423: 309-316.

48. Jinno A, Maruyama $\mathrm{Y}$, Ishizuka M, Kazusaka A, Nakamura A, et al. (2006) Induction of cytochrome P450-1A by the equine estrogen equilenin, a new endogenous aryl hydrocarbon receptor ligand. J Steroid Biochem Mol Biol 98: 48-55.

49. Leibelt DA, Hedstrom OR, Fischer KA, Pereira CB, Williams DE (2003) Evaluation of chronic dietary exposure to indole-3-carbinol and absorption-enhanced 3,3'-diindolylmethane in sprague-dawley rats. Toxicol Sci 74: 10-21. 
50. Bertazzi PA, Zocchetti C, Guercilena S, Consonni D, Tironi A, et al (1997) Dioxin exposure and cancer risk: a 15-year mortality study after the "Seveso accident". Epidemiology 8: 646-652.

51. Viel JF, Clément MC, Hägi M, Grandjean S, Challier B, et al. (2008) Dioxin emissions from a municipal solid waste incinerator and risk of invasive breast cancer: a population-based case-control study with GISderived exposure. Int J Health Geogr 7: 4.

52. Tritscher AM, Clark GC, Sewall C, Sills RC, Maronpot R, et al. (1995) Persistence of TCDD-induced hepatic cell proliferation and growth of enzyme altered foci after chronic exposure followed by cessation of treatment in DEN initiated female rats. Carcinogenesis 16: 2807-2811.

53. Holcomb M, Safe S (1994) Inhibition of 7,12-dimethylbenzanthraceneinduced rat mammary tumor growth by 2,3,7,8-tetrachlorodibenzo-pdioxin. Cancer Lett 82: 43-47.

54. Gierthy JF, Bennett JA, Bradley LM, Cutler DS (1993) Correlation of in vitro and in vivo growth suppression of MCF-7 human breast cancer by 2,3,7,8-tetrachlorodibenzo-p-dioxin. Cancer Res 53: 3149-3153.

55. Wang F, Hoivik D, Pollenz R, Safe S (1998) Functional and physical interactions between the estrogen receptor $\mathrm{Sp} 1$ and nuclear aryl hydrocarbon receptor complexes. Nucleic Acids Res 26: 3044-3052.

56. Duan R, Porter W, Samudio I, Vyhlidal C, Kladde M, et al. (1999) Transcriptional activation of c-fos protooncogene by 17beta-estradiol: mechanism of aryl hydrocarbon receptor-mediated inhibition. Mol Endocrinol 13: 1511-1521.

57. Klinge CM, Bowers JL, Kulakosky PC, Kamboj KK, Swanson HI (1999) The aryl hydrocarbon receptor (AHR)/AHR nuclear translocator (ARNT) heterodimer interacts with naturally occurring estrogen response elements. Mol Cell Endocrinol 157: 105-119.

58. Ricci MS, Toscano DG, Mattingly CJ, Toscano WA Jr (1999) Estrogen receptor reduces CYP1A1 induction in cultured human endometrial cells. J Biol Chem 274: 3430-3438.

59. Ohtake F, Baba A, Takada I, Okada M, Iwasaki K, et al. (2007) Dioxin receptor is a ligand-dependent E3 ubiquitin ligase. Nature 446: 562-566.

60. Spink DC, Eugster HP, Lincoln DW 2nd, Schuetz JD, Schuetz EG, et al. (1992) 17 beta-estradiol hydroxylation catalyzed by human cytochrome P450 1A1: a comparison of the activities induced by 2,3,7,8tetrachlorodibenzo-p-dioxin in MCF-7 cells with those from heterologous expression of the cDNA. Arch Biochem Biophys 293: 342-348.

61. Spink DC, Johnson JA, Connor SP, Aldous KM, Gierthy JF (1994) Stimulation of 17 beta-estradiol metabolism in MCF-7 cells by bromochloro- and chloromethyl-substituted dibenzo-p-dioxins and dibenzofurans: correlations with antiestrogenic activity. J Toxicol Environ Health 41: 451-466.

62. Oenga GN, Spink DC, Carpenter DO (2004) TCDD and PCBs inhibit breast cancer cell proliferation in vitro. Toxicol In Vitro 18: 811-819.

63. McDougal A, Wormke M, Calvin J, Safe S (2001) Tamoxifen-induced antitumorigenic/antiestrogenic action synergized by a selective aryl hydrocarbon receptor modulator. Cancer Res 61: 3902-3907.

64. Abdelrahim M, Smith R 3rd, Safe S (2003) Aryl hydrocarbon receptor gene silencing with small inhibitory RNA differentially modulates Ahresponsiveness in MCF-7 and HepG2 cancer cells. Mol Pharmacol 63: 1373-1381.

65. Hall JM, Barhoover MA, Kazmin D, McDonnell DP, Greenlee WF, et al. (2010) Activation of the aryl-hydrocarbon receptor inhibits invasive and metastatic features of human breast cancer cells and promotes breast cancer cell differentiation. Mol Endocrinol 24: 359-369.

66. Ma Q, Whitlock JP Jr (1996) The aromatic hydrocarbon receptor modulates the Hepa 1clc7 cell cycle and differentiated state independently of dioxin. Mol Cell Biol 16: 2144-2150.

67. Chen I, McDougal A, Wang F, Safe S (1998) Aryl hydrocarbon receptormediated antiestrogenic and antitumorigenic activity of diindolylmethane. Carcinogenesis 19: 1631-1639.

68. McDougal A, Sethi Gupta M, Ramamoorthy K, Sun G, Safe SH (2000) Inhibition of carcinogen-induced rat mammary tumor growth and other estrogen-dependent responses by symmetrical dihalo-substituted analogs of diindolylmethane. Cancer Lett 151: 169-179.

69. Meng Q, Yuan F, Goldberg ID, Rosen EM, Auborn K, et al. (2000) Indole-3-carbinol is a negative regulator of estrogen receptor-alpha signaling in human tumor cells. J Nutr 130: 2927-2931.

70. Hong C, Firestone GL, Bjeldanes LF (2002) Bcl-2 family-mediated apoptotic effects of 3,3'-diindolylmethane (DIM) in human breast cancer cells. Biochem Pharmacol 63: 1085-1097.

71. Greenlee WE, Hushka LJ, Hushka DR (2001) Molecular basis of dioxin actions: evidence supporting chemoprotection. Toxicol Pathol 29: 6-7.

72. Hong C, Kim HA, Firestone GL, Bjeldanes LF (2002) 3,3'Diindolylmethane (DIM) induces a G(1) cell cycle arrest in human breast cancer cells that is accompanied by Spl-mediated activation of p21(WAF1/CIP1) expression. Carcinogenesis 23: 1297-1305.

73. Trapani V, Patel V, Leong CO, Ciolino HP, Yeh GC, et al. (2003) DNA damage and cell cycle arrest induced by 2-(4-amino-3-methylphenyl)-5fluorobenzothiazole (5F 203, NSC 703786) is attenuated in aryl hydrocarbon receptor deficient MCF-7 cells. Br J Cancer 88: 599-605.

74. Barhoover MA, Hall JM, Greenlee WF, Thomas RS (2010) Aryl hydrocarbon receptor regulates cell cycle progression in human breast cancer cells via a functional interaction with cyclin-dependent kinase 4 . Mol Pharmacol 77: 195-201.

75. Müller A, Homey B, Soto H, Ge N, Catron D, et al. (2001) Involvement of chemokine receptors in breast cancer metastasis. Nature 410: 50-56.

76. Hsu EL, Yoon D, Choi HH, Wang F, Taylor RT, et al. (2007) A proposed mechanism for the protective effect of dioxin against breast cancer. Toxicol Sci 98: 436-444.

77. Safe S, Qin C, McDougal A (1999) Development of selective aryl hydrocarbon receptor modulators for treatment of breast cancer. Expert Opin Investig Drugs 8: 1385-1396.

78. Hall JM, McDonnell DP (2005) Coregulators in nuclear estrogen receptor action: from concept to therapeutic targeting. Mol Interv 5: 343-357.

79. Hestermann EV, Brown M (2003) Agonist and chemopreventative ligands induce differential transcriptional cofactor recruitment by aryl hydrocarbon receptor. Mol Cell Biol 23: 7920-7925.

80. McDougal A, Gupta MS, Morrow D, Ramamoorthy K, Lee JE, Safe SH (2001) Methyl-substituted diindolylmethanes as inhibitors of estrogeninduced growth of T47D cells and mammary tumors in rats. Breast Cancer Res Treat 66: 147-157.

81. McDougal A, Wilson C, Safe S (1997) Inhibition of 7,12dimethylbenz[a]anthracene-induced rat mammary tumor growth by aryl hydrocarbon receptor agonists. Cancer Lett 120: 53-63.

82. Bradlow HL (2008) Review. Indole-3-carbinol as a chemoprotective agent in breast and prostate cancer. In Vivo 22: 441-445.

83. De Laurentiis M, Arpino G, Massarelli E, Ruggiero A, Carlomagno C, et al. (2005) A meta-analysis on the interaction between HER-2 expression and response to endocrine treatment in advanced breast cancer. Clin Cancer Res 11: 4741-4748.

84. Dawood S, Cristofanilli M (2007) Endocrine resistance in breast cancer: what really matters? Ann Oncol 18: 1289-1291.

85. Taurin S, Allen KM, Scandlyn MJ, Rosengren RJ (2013) Raloxifene reduces triple-negative breast cancer tumor growth and decreases EGFR expression. Int J Oncol 43: 785-792.

86. O'Donnell EF, Koch DC1, Bisson WH2, Jang HS1, Kolluri SK3 (2014) The aryl hydrocarbon receptor mediates raloxifene-induced apoptosis in estrogen receptor-negative hepatoma and breast cancer cells. Cell Death Dis 5: e1038.

87. Meng LH, Kohlhagen G, Liao ZY, Antony S, Sausville E, et al. (2005) DNA-protein cross-links and replication-dependent histone H2AX phosphorylation induced by aminoflavone (NSC 686288), a novel anticancer agent active against human breast cancer cells. Cancer Res 65: 5337-5343.

88. McLean L1, Soto U, Agama K, Francis J, Jimenez R, et al. (2008) Aminoflavone induces oxidative DNA damage and reactive oxidative 
Citation: Hall JM (2014) The Aryl-hydrocarbon Receptor (AhR) as a Therapeutic Target in Human Breast Cancer. J Steroids Horm Sci 5: 140. doi:10.4172/2157-7536.1000140

Page 7 of 7

species-mediated apoptosis in breast cancer cells. Int J Cancer 122: 1665-1674.

89. Callero MA1, Suárez GV, Luzzani G, Itkin B, Nguyen B, et al. (2012) Aryl hydrocarbon receptor activation by aminoflavone: new molecular target for renal cancer treatment. Int J Oncol 41: 125-134
90. Brinkman AM, Wu J, Ersland K, Xu W1 (2014) Estrogen receptor Î \pm and aryl hydrocarbon receptor independent growth inhibitory effects of aminoflavone in breast cancer cells. BMC Cancer 14: 344 . 